Беларускі дзяржаўны педагагічны ӱніверсітэт імя Максіма Танка Факультэт пачатковай адукацыі

Кафедра беларускага і рускага мовазнаўства

tel. +375 297537133

e-mail: alena08@tut.by

ORCID ID: https://orcid.org/0000-0002-5774-5236

\title{
Антрапацэнтрычныя зааморфныя метафары ў беларускай і польскай мовах
}

Ключавыя словы: метафара, антрапацэнтрычная зааморфная метафара, заонім, беларускай мова, польская мова.

Вывучэнне метафары як лінгвістычнай з'явы вылучаецца шматаспектнасцю і разнастайнасцю. У навуковай літаратуры метафара разглядаецца не толькі як вобразны сродак, але і як сродак пазнання свету і адлюстравання ведаў у форме моўных знакаў: “... metafora potoczna jest znakomitym zbiorem danych językowych, na których podstawie można odtwarzać sposob myślenia użytkownikow języka o świecie, o otaczającej rzeczywistości" [Tokarski 1991, 145]. А.А. Апарына адзначае асаблівасці, якія робяць гэты від другаснай намінацы ўніверсальным сродкам вывучэння працэсаў мыслення [Опарина 1994, 145]:

- метафара фарміруецца на аснове рэальнага ці ўяўнага падабенства аб'ектаў наваколля, такім чынам яна заснавана на фундаментальнай для чалавечага мыслення здольнасці ўстанаўліваць падабенства паміж рознымі класамі аб'ектай;

- яна з'яўляецца адным з вядучых спосабаў вербалізацыі паняццяў, на аснове якога будуецца ӱвесь комплекс уяўленняў пра прадмет ці з'яву;

- метафара знаходзіць сваё моўнае ўвасабленне толькі ў пэўным культурным кантэксце, як частка культуры яна мае аксіялагічны характар; 
- метафара мае антрапацэнтрычны характар, бо меркай усіх рэчай з'яўляецца чалавек;

- розныя мовы карыстаюцца аднолькавымі тыпамі метафарычных пераносаў, а розніца ў метафарычнай вербалізацыі свету звязана з розным успрыняццем навакольнага асяроддзя тым ці іншым этнасам.

Невыпадкова ў сучаснай лінгвістыцы асабліва важнае значэнне набываюць спробы міжкультурнага даследавання метафар, што дае магчымасць зразумець спецыфіку этнічнай самасвядомасці.

Прадметам нашага аналізу сталі антрапацэнтрычныя зааморфныя метафары беларускай і польскай моў. Такі выбар абумоўлены некалькімі прычынамі. Па-першае, антрапацэнтрызм метафары можна разглядаць не толькі як спосаб разумення навакольнага свету, калі у яго цэнтры стаіць чалавек, аднак і як імкненне чалавека ацаніць самога сябе $\breve{y}$ навакольным свеце. Р. Такарскі адзначае: "Językoznawca może jedynie stwierdzić, czy dane językowe podsuwają jakieś przesłanki, które pokazyłyby, jak człowiek jako podmiot działań językowych ocenia siebie, jakie wartości preferuje bądź odrzuca" [Tokarski 1991, 145]. Па-другое, метафарычны перанос жывёла $\rightarrow$ чалавек з'яўляецца адным з універсальных у мовах свету, зааморфныя метафары маюць дакладную семантычную арганізацыю і ярка выражаную нацыянальную спецыфіку. Жыццёвасць такіх метафар у мове тлумачыць наступным чынам: "Она [метафара - А.В.] представляет своего рода двойную «проекцию», в том смысле, что мы не только используем воображаемый (и в то же время основанный на чувственном опыте) «образ» животного для характеристики самого человека, но и, в силу антропоцентрического измерения мира, наделяем животных «человеческими» свойствами" [Гаврилюк 2012].

Матэрыялам для аналізу паслужылі метафары, зафіксаваныя у тлумачальных слоўніках беларускай і польскай мой [Тлумачальны слоўнік беларускай мовы 1977-1984; Słownik języka polskiego]. Агульны аб’ём прааналізаванага матэрыялу склаў каля 200 метафарычных адзінак.

Метафарычныя намінацыі, якія апісваюць чалавека, выкарыстойваюцца, як правіла, для яго экспрэсіўнай характарыстыкі: яны характарызуюць як станойчыя, так і адмойныя якасці чалавека.

Антрапацэнтрычныя зааморфныя метафары апісваюць практычна ўсе бакі чалавечай асобы: знешнасць, характар, паводзіны, сацыяльныя якасці. Паколькі такія метафары не толькі называюць, але і перадаюць ацэнку тых ці іншых чалавечых якасцей, то аналіз такіх вобраз- 
ных слой дае магчымасць зразумець прыярытэты і жыццёвыя каштоўнасці этнасу.

Зааморфныя метафары, якія апісваюць знешнасць чалавека, у беларускай мове складаюць $10 \%$ ад агульнай колькасці прааналізаваных метафар, у польскай мове $-12 \%$. Толькі адзінкавыя метафары дзвюх моў маюць станоўчую канатацыю: арол 'пра чалавека мужнай прыгажосці, адважнага, удалага, смелага', kotka 'o przymilnej, młodej kobiecie'. Значная частка метафар гэтай групы перадае адмойную ацэнку і апісвае такія якасці, як рост чалавека: маляўка 'пра дзіця або чалавека маленькага росту', karakan 'człowiek niskiego wzrostu'; яго целасклад: слон 'аб тоўстым непаваротлівым чалавеку', słon 'o człowieku otyłym i niezgrabnie się poruszającym'; узрост і знешнасць: ropucha 'o starszej, tęgiej, brzydkiej kobiecie'; неахайнасць: свіння 'пра бруднага, неахайнага чалавека'.

Другую па колькасці групу антрапацэнтрычных метафар у дзвюх мовах складаюць словы, што апісваюць паводзіны чалавека. Практычна ўсе яны маюць негатыўную канатацыю і дазваляюць зразумець, якія аспекты паводзін з'яўляюцца непрымальнымі для беларускага і польскага этнасу. Гэта гаварлівасць (у беларускай мове): салавей 'пра гаваруна, балабона, які прыгожа гаворыць, многа абяцае', сарока 'пра балбатлівага, шумнага чалавека', шчабятун 'той, хто многа, безупынку гаворыць', панурасць (у польскай мове): borsuk 'człowiek ponury, skryty, lubiący samotność', dzik 'człowiek nietowarzyski'; задзірыстасць: певень 'задзірысты чалавек, забіяка', kogut 'człowiek czupurny, zadziorny'; дакучлівасць: гаўкала 'пра надаедлівага сварлівага чалавека', osa 'o kimś uszczypliwym, dokuczliwym'.

Метафары, якія апісваюць характар, складаюць у абедзвюх мовах дастаткова шматлікую групу: $20 \%$ у беларускай, $23 \%$ у польскай. Адмойнымі якасцямі характару з'яўляюцца адсутнасць розуму: авечка 'пра някемлівага дурнаватага чалавека', ішак 'пра ўпартага неразумнага чалавека', dudek 'głupiec', osioł 'o człowieku głupim lub upartym'; злосць: вылдра 'пра злую няўжыўчывую жанчыну', звер 'пра вельмі злога, жорсткага чалавека', gad 'o człowieku złym, fałszywym', jaszczurka 'o człowieku podstępnym, fałszywym, złośliwym'; хітрасць і ашуканства: ліс 'пра хітрага, ліслівага чалавека', жук 'пра хітрага, пранырлівага чалавека', kret 'o człowieku działającym podstępnie'. Да станоўчых якасцей характару можна аднесці смеласць: леў 'той, хто вызначаецца магутнай сілай, смеласцю, адвагай і пад.', orlica 'o kobiecie odważnej' і жывасць: уюн 'рухавы, жвавы чалавек', kоza 'о żywej, wesołej dziewczynie'. 
Самую вялікую групу антрапацэнтрычных зааморфных метафар у дзвюх мовах складаюць словы, што намінуюць чалавека з пункту гледжання яго сацыяльных якасцей. Такія метафары ў беларускай мове складаюць $54 \%$ ад агульнай колькасці, у польскай - 39\%. Гэтыя метафары называюць людзей па іх адносінах да іншых членаў соцыуму: n'яўка 'крывапівец, паразіт, прыгнятальнік', павук 'той, хто эксплуатуе каго-н.', hiena 'o człowieku bezwzględnym, żerującym na nieszczęściu innych'; паводле яго жыццёвых пазіцый: nanyzай 'пра чалавека, які не мае свайго погляду, паўтарае чужыя словы, думкі', хамелеон 'пра чалавека, які часта мяняе свае погляды і думкі у залежнасці ад абставін', kameleon 'o człowieku często i łatwo zmieniającym poglądy, zainteresowania, sympatie', piesek 'o kimś trudniącym się donosicielstwem, będącym na czyichś usługach'; паводле месца, якое чалавек займае ў грамадстве: зубр 'пра буйнога спецыяліста, уплывовую асобу ў якой-н. галіне дзейнасці', кim 'пра чалавека, які мае выключна важнае значэнне у якой-н. галіне, сферы дзейнасці', тля 'пра нікчэмнага чалавека', płotka 'osoba mało znacząca'; паводле адносін да працы: байбак 'пра непаваротлівага, гультаяватага чалавека; абібок, гультай', труцень 'той, хто не працуе, а жыве за кошт працы другіх, лодар', leming 'młoda, wykształcona osoba mieszkająca w dużym mieście, zwykle pracująca w korporacji i dobrze zarabiająca', krowa 'o kobiecie niezgrabnej, ociężałej, leniwej’.

Аднак найбольшая частка метафар чацвёртай групы намінуе чалавека паводле таго, як да яго ставяцца іншыя людзі. Такія метафары могуць выражаць як адмоўную, так і станоўчую ацэнку. Так, да метафар са станоўчай канатацыяй можна аднесці словы галубка 'узжываецца як ласкавы зварот да жанчыны', каток 'ласкавы зварот да хлопчыка', ластаўка 'ласкавая назва жанчыны, дзяўчыны, дзячынкі'; gotębica 'kobieta', kotek 'pieszczotliwe określenie używane w odniesieniu do bliskich, miłych osób obu płci', kurczattko 'o kimś małym, delikatnym, zwłaszcza o dziecku lub o drobnej dziewczynie'. Негатыўныя адносіны да чалавека перадаюць метафары acnid 'пра благога, падступнага чалавека', груган 'пра шкоднага, небяспечнага чалавека', bydle 'o człowieku wyjątkowo podłym lub niekulturalnym', kret 'o człowieku działającym podstępnie', gadzina 'o człowieku podłym'.

Праведзены аналіз дазваляе зрабіць выснову, што і для беларускай, і для польскай культуры вартасць чалавека вызначаецца яго ўменнем жыць у соцыуме, наладжваць адносіны з іншымі людзьмі.

Найчасцей назвы жывёл ужываюцца для негатыўнай характарыстыкі чалавека. Польскія даследчыкі звязваюць гэта 3 антрапацэн- 
трычным характарам вобразу свету: "Ów antropocentryzm, przypisując człowiekowi cechę bycia dobrym, wartościowym, rownocześnie odmawia takiej wartości tej cząstce świata, ktora jest do człowieka najbardziej podobna, ale przecież inna - światu zwierząt. Właśnie zwierzęta, a nie świat roślinny czy nieożywiony, są regularnie wartościowane negatywnie" [Tokarski 1991, 151]. Аднак гэта не можа растлумачыць выпадкі, хоць і рэдкія, з'яўлення станоўчых канатацый у зааморфных метафар. Таму важным для міжкультурнага даследавання метафар з'яўляецца і аналіз падстаў метафарызацыі. Механізм утварэння метафар - гэта дастаткова складаны і не да канца зразумелы працэс. У навуковай літаратуры выказваюцца розныя погляды на праблему ўтварэння метафарычных пераносай. Адзін з падыходаў заключаецца ў тым, што метафарычны перанос адбываецца на аснове агульнага семантычнага кампанента лексем. Аднак зааморфныя метафары маюць семантычна-культурную матывацыю [Szerszunowicz 2009, 219], узнікаюць на аснове канататыўных прымет, асацыяцый, якія не знаходзяць адлюстравання ў структуры лексічнага значэння. Такія канатацыі часта ўяўляюць сабой своеасаблівую культурную памяць, у якой захоўваюцца звесткі пра прататыпы. Прычым асацыятыўныя сувязі могуць насіць як агульначалавечы, так і нацыянальна спецыфічны характар. Так, у беларускай і польскай мовах слон/stoń асацыіруецца 3 нечым вялікімі і няўклюдным, што адлюстравалася ў пераносным значэнні адпаведных лексем: слон 'аб тоўстым непаваротлівым чалавеку' - słoń 'o człowieku otyłym i niezgrabnie się poruszającym'. Метафара адлюстроўвае прататыпічнае ўяўленне пра слана праз прыкмету знешняга выгляду. Для носьбітаў кітайскай культуры, як адзначае М.А. Гаўрылюк, слон асацыруецца $з$ нечым велічным, узвышаным, што ўражвае сваёй сілай і магутнасцю. Магчыма, прычыны з'яўлення такіх ацэнак у вобраза слана абумоўлены ўплывам будызму, дзе жывёла лічыцца адным з перайвасабленняў Буды [Гаврилюк 2012].

Метафары, што ӱзнікаюць на аснове знешняга ўспрыняцця жывёлы, як правіла, не патрабуюць тлумачэння, як, напрыклад: хамелеон 'пра чалавека, які часта мяняе свае погляды і думкі у залежнасці ад абставін' - kameleon 'o człowieku często i łatwo zmieniającym poglądy, zainteresowania, sympatie'. Узнікненне метафары звязана са здольнасцю хамелеона мяняць колер і малюнак скуры, таму падстава метафарызацыі падаецца зразумелай, невыпадкова назойнік хамелеон з'яўляецца сімвалам зменлівасці ў рускай, італьянскай, англійскай мовах.

Аднак, практычна немагчыма растлумачыць, чаму асёл выступае ўвасабленнем упартасці, пчала ці мурашка - працавітасці і г.д. 
Нам падаецца, што прычыны ўзнікнення такіх канатацый маюць глыбокія карані і звязаны з вельмі старажытнымі ўяўленнямі чалавецтва. Спашлёмся на даследаванне А.Голана, які на аснове археалагічных і этнаграфічных дадзеных дае сваё тлумачэнне ўзнікненню станойчых і адмойных адносін да жывёл. Даследчык сцвярджае, што ўсе жывёлы належалі да ніжняга (хтанічнага) або да вышэйшага свету (свету нябёсаў). Як правіла, хтанічныя жывёлы надзяляліся самымі горшымі якасцямі, што і знайшло адлюстраванне ў моўных метафарах.

Так, непрыязныя адносіны да асла ӱзніклі таму, што ӱ старажытнасці ён уяўляў злое і звергнутае боства [Голан 1993, 48], што і паслужыла падставай для з'яўлення метафар у беларускай і польскай мовах: aсёл 'пра дурнога, тупога, упартага чалавека' - osiot 'o człowieku głupim lub upartym'. Да хтанічных істот адносіўся і баран, які сімвалізаваў расліннасць і быў звязаны з зямлёй. Магчыма, гэтым і абумоўлены негатыўныя асацыяцыі, звязаныя з гэтай жывёлай: баран 'пра тупога, някемлівага чалавека' - baran 'człowiek nieinteligentny'.

Змяя у міфалогічных поглядах індаеўрапейцаў мае складаную, часам супярэчлівую сімволіку: з аднаго боку, яна ўвасабляе мудрасць, выступае захавальнікам сям'i, з другога боку, як істота, што належыць ніжняму свету, увасабляе сабой зло. У біблейска-хрысціянскай традыцыі змяя разглядаецца як увасабленне д'ябла [Гура 1997, 280]. У беларускіх і польскіх метафарах замацавалася ўяўленне пра змяю як істоту, што нясе зло: гадзюка 'пра небяспечнага шкоднага чалавека'; гадзіна 'пра небяспечнага шкоднага чалавека'; змяя 'пра каварнага, злога чалавека' - gadzina 'o człowieku podłym'; waż 'o człowieku chytrym, podstępnym'; żmija 'o człowieku złym i podstępnym'.

Большасць птушак (ластаўку, салаўя, бусла і інш.) славяне адносілі да верхняга свету, лічылі іх чыстымі, боскімі, светлымі. Сярод ix галубка, галубок/gotabka, gotabek. Уяўленне пра голуба як пра боскую птушку замацавана ў хрысціянскай традыцыі [Гура 1997, 612]. Вобраз голуба мае шлюбную сімволіку: гэта ўлюбёны вобраз у вясельных песнях, сімвал вернасці ў каханні, а два галубкі традыцыйна сімвалізуюць сабой закаханых. Невыпадкова ў беларускай і польскай мовах словы галубка, галубок/gołabka, gołabek ужываецца як ласкавы зварот да жанчыны ці мужчыны, каго-небудзь блізкага: галубка 'ӱжываецца як ласкавы зварот да жанчыны'; галубок 'ужываецца як ласкавы зварот да маладзейшага за сябе мужчыны' - gotabka 'pieszczotliwie o kobiecie o łagodnym usposobieniu'; gołabek 'pieszczotliwie o kimś bliskim'. 
Такім чынам, можна меркаваць, што развіццё пераносных значэнняў назойнікаў асёл/osiot, баран/baran, змяя / zmija, галубка, галубок/gotabka, gotabek абумоўлена агульначалавечымі (або агульнаславянскімі) асацыяцыямі. Існаванне нацыянальна спецыфічнага погляду на свет, на месца $\ddot{y}$ ім той ці іншай жывёл прыводзіць да разыходжання ў пераносных значэнняў назойнікаў - назваў жывёл. Таму пры супастаўляльным аналізе зааморфных метафар можна вылучыць тры тыпы семантычных суадносін: 1) выпадкі супадзення пераносных значэнняў, 2) выпадкі частковага супадзення, калі адны семантычныя кампаненты ў розных мовах падобныя, а іншыя адрозніваюцца, 3) выпадкі поўнага разыходжання значэння заамарфізмай.

Да першага тыпу семантычных суадносін мы аднеслі метафары, якія маюць падобныя ці вельмі блізкія значэнні: мядзведзь 'пра няўклюднага, непаваротлівага дужага чалавека' - niedźwiedź 'o człowieku niezgrabnym, niezdarnym'; карова 'пра тоўстага, нязграбнага чалавека (звычайна пра жанчыну)' - krowa 'o kobiecie niezgrabnej, ociężałej, leniwej'; малnа 'аб вельмі непрыгожым чалавеку' - małpa 'o człowieku, zwłaszcza złośliwym lub brzydkim'; вылра 'пра злую няўжыўчывую жанчыну' - wydra 'o kobiecie niesympatycznej, ubranej lub zachowującej się wyzywająco'; nanyгаŭ 'пра чалавека, які не мае свайго погляду, паўтарае чужыя словы, думкі' - papuga 'o kimś powtarzającym coś bezmyślnie'; лic 'пра хітрага, ліслівага чалавека' - lis 'o człowieku sprytnym, podstępnym'; uяля 'пра бязвольнага, безадказнага ці занадта прастадушнага, няхітрага чалавека' - ciele 'o kimś niezaradnym lub nierozgarniętym'.

Многія з гэтых метафар заснаваны на знешніх уяўленнях пра жывёлу, асаблівасцях яе паводзін. Так, пераноснае значэнне назоўніка мядзведзь/niedźwiedź узнікла на аснове знешніх асацыяцый, уяўлення пра мядзведзя як няўклюдную, нязграбную жывёлу.

Агульнаславянскае слова n'яўка/pijawka паходзіць ад дзеяслова niџb. Вядома, што гэты від чарвякой харчуецца крывёй, што і паслужыла асновай для метафарычнага пераносу: n'яўка 'крывапівец, паразіт, прыгнятальнік' - pijawka 'ktoś bogacący się kosztem innych ludzi'.

Да частковых супадзенняў можна аднесці выпадкі, калі метафары супадаюць толькі ӱ адным са сваіх значэнняў. Напрыклад, словы певень / kogut: певень 'задзірысты чалавек, забіяка' - kogut 'człowiek czupurny, zadziorny'; 'mężczyzna mający dużą sprawność seksualną'. Як бачым, у польскай мове слова kogut мае два пераносныя значэнні. У поглядах славян певень з'яўляецца ўвасабленнем сонца, сімвалам урадлівасці, аднак вызначаецца задзірлівым характарам. У беларус- 
кай і польскай мовах назоўнік ужываецца для характарыстыкі паводзін чалавека. Аднак у польскай мове, акрамя ўяўлення пра характар птушкі, замацавалася разуменне пеўня як сімвала ўрадлівасці.

Погляды на свінню як нячыстую жывёлу існуюць ва ўяўленні многіх народаў свету. Вядома, што ў розных рэлігійных сістэмах дзейнічае забарона на ӱжыванне свініны. У пераносных значэннях слова свіння / świnia замацаваліся гэтыя ўяўленні, аднак яны перанесены на сферу маральных каштойнасцей: знешні бруд заўсёды асацыруецца з брудам маральным. Таму ў беларускай і польскай мовах свіння з'яўляецца увасабленнем нявыхаванага чалавека, які няправільна паводзіць сябе у грамадстве. Аднак у беларускай мове слова свіння яшчэ ӱжываецца і для знешняй характарыстыкі чалавека: свіння 'пра бруднага, неахайнага чалавека'; 'нявыхаваны, грубы, некультурны чалавек'; 'пра чалавека, які незаслужана робіць каму-н. непрыемнасці; няўдзячны чалавек' - świnia 'o człowieku, który wyrządził komuś krzywdę'; 'o człowieku zachowującym się nieprzyzwoicie'.

Выпадкі несупадзення семантыкі метафар у розных мовах прадстаўлены двума варыянтамі. У першым словы у дзвюх мовах маюць пераноснае значэнне, але гэта значэнне не супадае. Да такіх прыкладаў можна аднесці слова арол/orzet. У метафарах беларускай і польскай мой увасоблена ўяўленне пра арла як цара птушак, гаспадара нябёс. Аднак у беларускай метафары рэалізуюцца семы прыгажосці і смеласці. А вось метафара польскай мовы апісвае чалавека, здольнага на незвычайныя рэчы: арол 'пра чалавека мужнай прыгажосці, адважнага, удалага, смелага' - orzeł 'o człowieku bardzo zdolnym, wyróżniającym się'.

Магчыма, дэфініцыя слова orzet, якая дае больш магчымасцяў для характарыстыкі чалавека,звязана з тым, што гэтая птушка займае вельмі значнае месца $\ddot{y}$ сістэме этнічных поглядаў палякаў: менавіта яна з'яўляецца сімвалам польскай дзяржавы. Адзначым, што ў польскай мове пераноснае значэнне набыла і назва самкі арла: orlica 'o kobiecie odważnej'. Падобнай метафары у беларускай мове не зафіксавана.

Назоўнік груган / kruk таксама ўжываецца ў дзвюх мовах з розным пераносным значэннем. Пры агульнасці негатыўнай канатацыі гэтыя метафары апісваюць розныя рысы характару чалавека: груган 'пра шкоднага, небяспечнага чалавека' - kruk 'o ludziach złych, żerujących na czyimś nieszczęściu'.

Жаба/ropисhа у міфічных уяўленнях славян звязана з ніжнім светам, адносіцца да хтанічных істот, што абумоўлівае негатыўныя адносіны да гэтай жывёлы. Некаторыя славянскія легенды расказваюць, 
што некалі жаба была жанчынай. Жаночая сімволіка жывёлы і негатыўная яе ацэнка, верагодна, і паслужылі асновай для ўтварэння пераноснага значэння назойніка ў польскай мове: ropucha 'o starszej, tęgiej, brzydkiej kobiecie'. Адна жаба ўспрымалася і як хатняя апякунка, нездарма адзін з папулярных казачных персанажаў славян - Жаба-царэўна. Магчыма, гэтыя ўяўленні і паслужылі асновай для уззнікнення пераноснага значэнне ў беларускай мове: жаба 'пагардлівае або дакорлівае абзыванне дзяцей'.

Другі варыянт несупадзення семантыкі метафары прадстаўлены словамі, якія ўжываюцца з пераносным значэннем толькі ў адной мове.

Так, у беларускай мове для абазначэння розных якасцей чалавека ўжываюцца назоўнікі: авечка 'пра някемлівага дурнаватага чалавека'; заяи 'пра безбілетнага пасажыра'; жук 'пра хітрага, пранырлівага чалавека'; кim 'пра чалавека, які мае выключна важнае значэнне у якой-н. галіне, сферы дзейнасці'; павук 'той, хто эксплуатуе каго-н.'; сокал 'пра смелага, прыгожага юнака, мужчыну'; чарвяк 'пра нікчэмнага, агіднага чалавека' і інш. Пераносныя значэнні ў назваў гэтых жывёл у польскай мове не зафіксаваныя.

Прычын такіх разыходжанняў можа быць некалькі, аднак часцей за ўсё яны абумоўлены спецыфікай нацыянальных асацыяцый, звязаных з той ці іншай жывёлай.

Так, назоўнік зубр у беларускай мове ӱжываецца са значэннем 'пра буйнога спецыяліста, уплывовую асобу ў якой-н. галіне дзейнасці'. Магчыма, фарміраванне падобнага метафарычнага значэння звязана $з$ тым, што зубр з'яўляецца сімвалам Беларусі. Гэта традыцыя мае хутчэй за ўсё кніжны характар і бярэ свой пачатак з XVI ст. з "Песні пра зубра" М. Гусоўскага. На нашу думку, гэтым можна растлумачыць і ӱжыванне з падобным пераносным значэннем слова зубр ва ўкраінскай мове: зубр 'про того, хто має великий досвід, знання в якійсь ділянці, відіграє керівну роль де-небудь'.

Для ласкавага звароту да жанчыны у беларускай мове выкарыстойваюцца назвы птушак зязюлька і ластаўка. Ластаўка лічыцца чыстай, святой птушкай, якая мае жаночую сімволіку. „Вобраз ластаўкі як райскай птушкі ўвасоблены і ў іншых вераваннях: яна прыносіць вясну і выклікае гаспадара $\ddot{y}$ зімовых песнях" [Беларуская міфалогія 2004, 281]. Усе гэтыя станойчыя асацыяцыі, магчыма, і паслужылі асновай для ўзнікнення метафары.

Зязюля займае асаблівае месца ў беларускай міфалогіi і беларускім фальклоры. Беларускімі збіральнікамі зафіксаваны некалькі сюжэтай так званага „зязюльчынага міфа” [Беларуская міфалогія 2004, 199]. 
Аб'ядноўвае гэтыя сюжэты адно: зязюля - гэта жанчына, ператво-

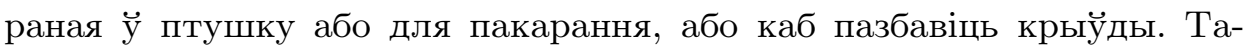
му жаночая сімволіка птушкі ў беларускіх уяўленнях прасочваецца вельмі выразна. Дарэчы, падобныя метафары не зафіксаваныя ӱ іншых усходнеславянскіх мовах, таму такі зварот можна лічыць тыпова беларускім.

Да божых, святых птушак адносіцца і салавей, які высока цэніцца за свой дасканалы спеў, што адлюстравалася у пераносным значэнні назоўніка: 'пра чалавека, які славіцца чыстым, прыгожым, пераважна высокім голасам, вакальным майстэрствам'. Аднак пазней на аснове гэтага значэння развілася новае, якое перадае іранічныя адносіны да чалавека, які шмат гаворыць: 'пра гаваруна, балабона, які прыгожа гаворыць, многа абяцае'.

Сарока, як дэманічная птушка, якая, паводле беларускіх павер'яў, падманула Бога [Беларуская міфалогія 2004, 452], надзяляецца адмойнымі рысамі, што знайшло адлюстраванне ў пераносным значэнні слова: 'пра балбатлівага, шумнага чалавека'.

У пераносным значэнні слова леў зафіксаваны ўяўленні пра гэту жывёлу як цара звярой: 'той, хто вызначаецца магутнай сілай, смеласцю, адвагай і пад.' .

У польскай мове для характарыстыкі чалавека ўжываюцца заонімы borsuk 'człowiek ponury, skryty, lubiący samotność'; chomik 'człowiek gromadzący zbędne zapasy'; hiena 'o człowieku bezwzględnym, żerującym na nieszczęściu innych'; mut 'osoba powolna, mało rozgarnięta lub uparta'; jastrzab 'wojowniczy, agresywny polityk', dudek 'głupiec' і інш. У беларускай мове гэтыя назойнікі ўжываюцца толькі ў прамым значэнні.

Прычыны разыходжанняў зной трэба шукаць у спецыфіцы нацыянальных асацыяцый, звязаных з той ці іншай жывёлай.

Так, бык у міфічных уяўленнях многіх народаў свету атаясамліваўся са старажытным богам зямлі. На думку А. Голан, яшчэ ў неалітычныя часы бык увасабляў сабой мужчынскую вытворчую сілу [Голан 1993, 54], што, па нашым меркаванні, і ӱвасобілася ў польскай метафары byk 'o dużym, silnym mężczyźnie'.

Міфалагізацыя вобраза аленя ўзнікла ў палеаліце [Голан 1993, 37] і адны з самых старажытных індаеўрапейскіх паданняў малююць гэтую жывёлу як ахвяру. Водгуллем гэтых паданняў, магчыма, і з'яйляецца польская метафара jeleń 'mężczyzna łatwo dający się oszukać'.

Гусь у касмаганічных міфах нярэдка выступае як увасабленне першабытнага хаосу, з якога нараджаецца новы свет. Як і многія жывёлы ніжняга свету, яна надзяляецца адмойнымі якасцямі, што мы і бачым 
у пераносным значэнні слова ў польскай мове: gęś 'o kobiecie naiwnej, głupiej'.

Да хтанічных істот адносяцца яшчарка і крот, таму назоўнікі jaszczurka i kret у польскай мове ўжываюцца для адмоўнай характарыстыкі чалавека: jaszczurka 'o człowieku złym, obłudnym'; kret 'o człowieku działającym podstępnie'.

Адной $з$ самых рана прыручаных чалавекам жывёл была каза. Як адзначаюць даследчыкі, у фальклоры многіх народаў на вобраз казы наклаліся дзве традыцыі - язычніцкая і хрысціянская. "У першай каза сімвалізавала сямейны лад, дабрабыт і ўрадлівасць. Паводле другой каза - стварэнне чорта, жывёліна, што цесна звязана 3 нячыстай сілай" [Беларуская міфалогія, 211]. Аднак у польскай мове, дарэчы як ва ўкраінскай і рускай, заонім kоza ўжываецца для абазначэння жывой, вясёлай дзяўчыны. Гэта дае магчымасць меркаваць, што ў аснову метафарычнага пераносу ляглі менавіта язычніцкія традыцыі.

Безумоўна, прыведзеныя тлумачэнні можна лічыць толькі гіпатэтычнымі, для больш дакладнага аналізу неабходны зварот да польскай міфалогіі і фальклору.

Такім чынам, назвы жывёл дастаткова часта ўжываюцца ў беларускай і польскай мовах для характарыстыкі чалавека. Зааморфныя метафары дазваляюць апісаць розныя бакі чалавечай асобы: знешнасць, характар, асаблівасці паводзін, месца і ролю ӱ грамадстве. Паколькі метафары не столькі называюць, колькі даюць характарыстыку тым ці іншым чалавечым якасцям, аналіз семантыкі слоў з пераносным значэннем дае магчымасць зразумець, што лічыцца станоўчым, а што адмоўным у тым ці іншым грамадстве.

Прычыны вялікай частотнасці зааморфных метафар і падставы, на якой адбываецца метафарычны перанос слоў - назваў жывёл, на наш погляд, трэба шукаць у старажытных уяўленнях славян. Так, універсальнасць пераносу жывёла $\rightarrow$ чалавек абумоўлена, па нашым меркаванні, старажытнымі архетыпамі, уяўленнямі пра жывёл-першапродкаў. Аднак розныя ўяўленні пра характар і паводзіны жывёл у прадстайнікой двух этнасаў прыводзяць да разыходжання ў значэнні моўных заамарфічных метафар. Як паказвае аналіз, нягледзячы на тое, што беларуская і польская мовы адносяцца да славянскіх і маюць шмат агульных лексічных рыс, у семантыцы метафар часцей назіраюцца выпадкі частковага супадзення значэння метафар і выпадкі поўнага несупадзення значэння метафар, што сведчыць пра адметнасці светапогляду беларускага і польскага народаў. 


\section{Літаратура}

Belaruskâ̂ mifalogiâ, 2004, Mìnsk. [Беларуская міфалогія, 2004, Мінск.]

Gavrilûk M.A., 2012, Zoomorfnâ̂ metafora v kitajskom i russkom âzykah: mež"âzykovye universalii i nacional'nâ̂ specifika [Гаврилюк M.А., 2012, Зооморфная метафора в китайском и русском языках: межъязыковые универсалии и начиональная специфика], [online], http://www.iling-ran.ru /library/psylingva/sborniki/Book1998. [08.08.2015]

Golan A., 1993, Mif i simvol, Moskva. [Голан А., 1993, Миф и символ. Москва.] Gura A.V., 1997, Simvolika životnyh v slavânskoj narodnoj tradicii, Moskva. [Гура А.В., 1997, Символика животных в славянской народной традиции, Москва.]

Oparina E.O., 1994, Rol' metafory v poznanii i verbalizacii znanij o mire, [v:] Struktury predstavleniâ znanij v âzyke, Moskva, s. 142-160. [Опарина E.O. 1994, Роль метафорь в познании и вербализации знаний о мире, [в:] Структуры представления знаний в языке, Москва, с. 142-160.]

Tlumačal'ny sloŭnik belaruskaj movy, 1977-1984, Mìnsk, t. 1-5. [Тлумачальны слоўнік беларускай мовы. 1977-1984, Мінск, т. 1-5.]

Stownik języka polskiego, [online], http://sjp.pwn.pl. [21.08.2017]

Szerszunowicz J., 2009, Pozorne ekwiwalenty jednowyrazowych konwencjonalnych metafor faunicznych w języku polskim i włoskim, "Studia Wschodniosławiańskie", t. 9, s. 217-237.

Tokarski R., 1991, Wartościowanie cztowieka w metaforach językowych, "Pamiętnik Literacki", 82/1, s. 144-157.

\section{ANTHROPOCENTRIC ZOOMORPHIC METAPHORS IN THE BELARUSIAN AND POLISH LANGUAGES}

S U M M A R Y

The article analyzes anthropocentric zoomorphic metaphors in the Belarusian and Polish languages. In two languages, animal names are used to characterize various qualities of a person: their appearance, character, behavior, place and role in society. Such metaphors not only denote a person, but also give them a positive or negative evaluation. And more often zoomorphic metaphors are used for negative characterization of a person.

Based on the analysis of the dictionary entries of the explanatory dictionaries of the Belarusian and Polish languages, cases of complete and partial similarity of semantics of metaphors are considered. Metaphors are distinguished, the meanings of which do not coincide completely, and metaphors that exist only in one of the languages. The author believes that the discrepancy in the semantics of zoomorphic metaphors in the Belarusian and Polish languages is due to the ancient concepts of the Slavs about animals. 